\title{
Natural Rights, Morality, and the Law
}

\section{Drum Peter}

The Australian Catholic University, 115 Victoria Parade, Fitzroy, Victoria, Australia.

Email: peter.drum@acu.edu.au

Received January $7^{\text {th }}, 2011$; revised January $24^{\text {th }}, 2011$; accepted February $7^{\text {th }}, 2011$.

\begin{abstract}
It is argued that despite attempts to discount the importance of natural rights for morality, they are fundamental to it; therefore, so too are natural rights to the legitimacy of the law.
\end{abstract}

Keywords: Rights, Justice, Law, Reasonableness

\section{Introduction}

The Constitution of the United States proclaims that everyone has certain inalienable rights, and the 1948 United Nations Universal Declaration of Human Rights articles many of these rights. Since these natural - inherent, human - rights are adjudged to be indefeasible, for positive law - man made law, the law of the land to have morally authority and adequacy, it must conform to and promote respecting natural rights. But, there have been and continue to be attacks upon the significance of these rights for morality, and thence for legality. The purpose of this paper is show that, to the contrary, natural rights are basic to morality; and, consequently, to the law.

\section{Reasonableness and Rights}

Argument and evidence both attest to the fact that “'man's good is to live according to reason and his evil to live outside'" [1]. For, regarding the former, human $e x$ cellence consists in persons being rational animals [2]. Therefore, if we are to be good, we must strive to be reasonable. And, regarding the latter, it is a natural expectation of everyone that they be reasonable. This is why Joseph Goebbels' propaganda machine tried to portray Hitler as a reasonable human being, and Nazism as a reasonable philosophy. Therefore, we need to be just, for justice "is complete virtue [reasonableness] in its fullest sense because he who possesses it can exercise virtue [reasonableness] not only in himself but towards his neighbour also." [3] (Not that a person can treat himself unjustly, but unless we do ourselves justice, we will do ourselves harm.) [4] Hence, Aristotle reminds us that "there really is, as everyone to some extent divines, a natural justice and injustice that is binding on all men, even those who have no association or covenant with each other.” [5] For, although temporally and regionally the natural law has not always been well understood - or has sometimes been simply ignored - it nevertheless is the case that "every culture has a concept of murder, distinguishing this from execution, killing in war, and other 'justifiable homicides'. The notions of incest and other regulations upon sexual behaviour, of restitution and reciprocity, of mutual obligations between parents and children - these and many other moral concepts are altogether universal.” [6]

Therefore, there are natural rights. For, justice concerns “'another's good"' [7] - it is about what belongs to somebody else. Thus, murder is considered to be an injustice because it involves taking another's life; and adultery another's spouse; and theft another's goods. Hence, St Augustine asks "What is more yours than you?" [8] He is rhetorically making the point that an individual is first and foremost their own person. St Thomas Aquinas expands this idea: “... belonging can have several meanings. The first is by way of identity, of which Augustine is speaking ... In a second way, something can belong to another as his possessions or his slave ... A third sense of something's belonging to someone is through origin alone ..." [9] In other words, natural rights involve ontological connectedness, so to have a right to a good is to have a connection to it over and above anyone else's. Identity is a straightforward instance of this; yet, as Aquinas indicates, there are other connections persons can have to the goods of life. For instance, farmers have connections to land through their fencing it and working it, and parents to children as they are their progeny [10]. This explains why such a thing as queue-jumping evokes resentment - someone further 
down the line has no business going ahead of those who are waiting their turn; and also why people get angry when they are slighted - they think what is due to them is a certain degree of respect [11]. Consequently, Jeremy Bentham puts the cart before the horse when he says that a right "is a child of law; from real laws come real rights, but from imaginary law, from 'laws of nature', come imaginary rights ..." [12] On the contrary, rights precede laws. Sophocles' Antigone's statement that "he 'Creon' has no right to keep me from my own" [13] attests to this - despite the king's ruling, she maintains that her brother Polynice's body belongs to her; so according the natural law, she is permitted to bury it.

Hence, the right to life is a basic right, for life is an identity value in humans - for us to be is for us to live. Furthermore, this right naturally generates other rights in persons; viz. to a fair share of the worldly goods they require for proper human living. Of course, in the context of scarce resources satisfying this right cannot always be guaranteed - lifeboats fill - however, it does mean that some cannot take more than they need of the world's goods at the expense of the more basic claims of not undeserving others. For example, if land is legitimately required for farming, squatters' runs can be carved up. (Naturally, this should not unduly disadvantage those who were there first, and compensation may be due to them for their part in opening-up the country.) So, when Alasdair MacIntyre says that there are no natural rights because "every attempt to give good reasons for believing that there are such rights has failed" [14] - he is mistaken. And, even if his claim that "there is no expression in any ancient or medieval language correctly translated by our expression of 'a right' until near the close of the middle ages" [15] is correct, that this entails that even if there were human rights "no one could have known that there were" [16] is also incorrect. For, the idea of natural justice has a very long history, and this is about our getting what in the natural order of things is our due. Thus, "indignation is pain caused by the sight of undeserved good fortune ... 'for example' ... the newly rich give us more offence by obtaining office through their riches than do those whose wealth is of long standing ... The reason is that what the latter have is felt to be really their own, but what the others have is not; what appears to have been always what it is regarded as real, and so the possessions of the newly rich do not seem to be really their own.” [17]

\section{Principles and Rights}

Peter Singer writes: "Why is it surprising that I have little to say about the nature of rights? It would only be surprising to one who assumes that my case ... is based upon rights ... But this is not my position at all. I have little to say about rights because rights are not important to my argument ... (With the benefit of hindsight, I regret that I did allow the concept of a right to intrude into my work so unnecessarily at this point; it would have avoided misunderstanding if I had not made this concession to popular rhetoric. )" [18] Singer maintains that although rights talk is not uncommon in everyday moral discussions - a fact which he just dismisses, but which is significant in itself - rights are unimportant in moral philosophy. This is because he thinks that utility is fundamental to ethics, so we should govern our behaviour according to the principle of the equal consideration of interests. [19] (He is echoing the words of the founding father of the movement, Jeremy Bentham, who states that rights are "rhetorical nonsense - nonsense upon stilts." [20]. So, although Singer does say that "equality is a basic ethical principle" [21], this should no be confused with the equality of persons in terms of their basic human rights. What he means is that utility requires that we "give equal weight in our moral deliberations to the like interests of all those affected by our actions" [22]; where “interests" means "anything people desire as 'being' in their interests" [23]. Thus, "the principle of equal consideration of interests acts like a pair of scales, weighing interests impartially. True scales favour the side where the interest is stronger or where several interests combine to outweigh a smaller number of similar interests; but they take no account of whose interests they are weighing." [24] Singer is confident that "the principle of equal consideration of interests shows straightforwardly why the most blatant forms of racism, like those of the Nazis, are wrong. For the Nazis were concerned only with the welfare of members of the 'Aryan' race, and the sufferings of Jews, Gypsies and Slavs were of no concern to them.” [25] But, even if their sufferings were considered, they still might have ended up being discounted by the sheer weight of the Aryan numbers. Then, the Nazi program could rightfully - and indeed should rightfully have gone ahead. This is morally obscene and absurd. For, even if it is countered that such a scenario is unlikely to happen, that in principle it is possible condemns the utility theory for discounting the rights of minorities. Furthermore, the theory is also condemned by that which is being adduced here to allay our fears - namely, the practical impossibility of evil triumphing by the numbers. For, this simply confirms the fact that the moral majority well understand that the currency of ethics is legitimate interests, not interests that are trivial and wicked. This is why we understand Elizabeth Anscombe, when she says that "if someone really thinks ... that it is an open question 'in ethics' whether such an action as procuring the judicial execution of the innocent should be quite excluded from consideration ... he shows a corrupt mind." 
[26] And, it is why we know that Alan Donagan is quite correct, when he says that "a community ... and individuals willing to accept benefits at the price of crimes committed upon other individuals degrade their humanity." [27] For, there are "many human qualities which are valued and yet resist utilitarian treatment, such as an unaccommodating passion for justice; certain sorts of courage; spontaneity; a disposition to resist such things as useful experiments on senile patients or the use of napalm on some people to secure (as it is supposed) the happiness of more people ..." [28] We ignore these facts at our peril, and it is wrong to do so for the sake of a theory.

In this context, R. G. Frey maintains however that the evidence is that the principle of utility trumps rights. For, "almost no one thinks that the right to freedom of speech extends to causing panic among passengers on an aeroplane, or that the right to privacy extends to precluding infringements by persons in great difficulty or danger, or that some general right not to be interfered with extends so far as to compel others to stand by and watch one die (e.g., because one holds some metaphysical/religious view about bodily evil.) The general point, then, that individual (moral) rights can be overridden by appeals to utility, is normally conceded." [29] He says that it is far-fetched to think of these as conflicts of rights situations [30], but it is hard to understand why he thinks this. For, lives are at stake in all of these cases; so, the freedom of speech and privacy examples can naturally be read as instances of fundamental rights taking precedence over lesser rights. And, in the other case, the dying person seems very confused, so we cannot simply let them die, unless it is clear they are legitimately asserting the right.

Frey also states that "if we take morality seriously and so try to live up to our principles, we shall behave in the way the right's proponent wants us to, without his having to postulate the right's existence.” [31] But, this argument seems overly simplistic. For, without more, "respect for life" as a basic principle of morality might, on the one hand, prescribe pacifism - that is, moral agents putting up with anything and everything, even unjust aggressions. Or, on the other, it might prescribe what we have just been considering, viz. expediency - morally discounting the rights of smaller numbers of people to maximise majority outcomes. Yet, both of these are clearly inconsistent with morality. And, if Frey qualifies his principle to accommodate this, what would be the basis for his doing so, if not at least an implicit recognition of the critical importance of moral rights? He maintains that "what is wrong with depriving someone of a decent wage is not that it infringes some alleged right of his to this or that income but that it ruins his life and the lives of those who depend upon him." [32] Thus, he thinks that a good per- son will respond to others' sufferings irrespective of whether or not they have rights. (Philanthropists, for instance, will avoid harming others and help them, whether or not this is due to their beneficiaries.) However, this is an impoverished and pernicious view of things. Firstly, because wage earners deserve the dignity of being recognised as more than merely recipients of noblesse oblige handouts. The Elephant Man's impassioned cry "I am not an animal - I am a human being!” is a worthiness demand, not simply the begging plea of someone wanting recognition. And, secondly, because on this account the particular virtue of charity - viz., that it is free giving - disappears. For, according to the argument, beneficent agents are merely doing what they are required to do, not something supererogatory. Furthermore, if rights considerations are omitted from the moral equation, how can a moral program of avoiding harm to others and helping them based simply upon the fact that they are capable of suffering pain and frustration explain how someone like Mrs Jellyby in Charles Dickens' Bleak House - who is very generous to the natives of Borrioboola-Gha whilst neglecting her own family - goes so hopelessly wrong?

In a similar spirit, Raimond Gaita argues that the concept of "inalienable rights" is "more abstract" than other moral concepts - such as the principle of respect for fellow human beings - and is therefore unhelpful [33]. However, it is not at all obvious that all fellow human beings are worthy of respect; so, unless this notion can be underpinned in some way, it too is unhelpful. (Gaita's objection to rights being abstract is, to say the least, incongruous; for it follows immediately upon his apparent willingness to accept of morality "its mystery.") [34] Gaita also contends that "the concept of rights is too thin (in the sense too mean) to invite us into a deepened understanding of the evil-doer and what he did ....A Nazi forced a rabbi to spit on the Torah scroll." [35] But, no-one thinks that the evil done is exhausted by the terrible injustice of it all - the Nazi's callousness and indifference is terrible too - but this does not mean that a deep understanding of this horror is in any way possible without considering moral rights. For, Plato maintains that "doing injustice is really the greatest of evils" [36], and the outrage one naturally feels when confronted by the case points in this direction, rather than towards the moral meanness of rights.

Gaita wishes to agree with Simone Weil, who argues that claims to rights "evoke a latent war and awaken the spirit of contention ... and so ... inhibit any possible impulse of charity on both sides." [37] However, the former is by no means true, nor is the latter. (Even the latter were true, this objection is irrelevant, since all the claimant wants is rights recognition, not charity.) As the American jurisprudent Joel Feinberg points out, rights claims 
can be asserted "coolly, automatically, with dignity and calm, or with embarrassment, regret, or even apology. Indeed they can be asserted without uttering any words at all, as when a person makes a claim to his coat by presenting his check token to the cloak room attendant.” [38] Gaita notes that Weil says that "if a young girl is forced into a brothel she will not talk about her rights. In such a situation the word would sound ludicrously inadequate." [39] Of course, Weil is quite possibly right - if things have come to this, alluding to her rights is unlikely to get her anywhere. But, nor probably will anything else. And, it is surely worth a try, particularly if her rights are protected by sanctions of law. For, then those forcing her into prostitution will have to consider what will happen to them if this is brought to the attention of authorities, and they are arrested.

Since all of these objections are unconvincing, the case for the importance of moral rights stands. There really is such a thing as "another's good"; therefore, doing injustice is the greatest of evils, because it deprives others of goods that are theirs. Thus, Aristotle's verdict, (using matricide as an example), that there are "some acts, perhaps, we cannot be forced to do, but ought rather to face death after the most fearful sufferings ...for what we are forced to do is base ..." [40] seems correct. For, however painful the consequences might be, we should steel ourselves to endure them. We have no right to take the life of anyone who is not a threat to us, especially the life of a parent.

\section{Moral Dilemmas and Rights}

It should be clear by now why utility theorists are naturally averse to rights. For, once these rights are recognised, the greatest good for the greatest number turns out to be nothing other than the order of natural justice. So, the good cannot be served by, for example, Dudley and Stephens killing and eating the cabin-boy. On the contrary, it requires that do not, even if this means their deaths. Therefore, Judith Jarvis Thomson's contention that in a situation where the Mafia will kill three other people unless Alfred kills Bert and he refuses to do so, "a particular just act may not be on balance good for people" [41] is false. For, why should it be thought that Alfred's refusal to kill an innocent man is not the lesser of two evils? Although the prospect of three people being murdered is terrible, it would be much worse if their futures were secured at the cost of reasonable people themselves committing injustices. Thus, "he who violates the law can never recover by any success, what he has already lost in departing from virtue.” [42] Again, Thomson's argument that "it is better for us that the people among whom we live be just than that they not be just. A moral regime under which I can make you owe people something simply by threatening not to pay my own debts to them is a moral regime with a massive free-rider problem, and thus a regime that would be bad for all of us" [43] is also flawed, as it just means that the virtues should be upheld in all cases for rule-utilitarian reasons. This thesis is morally absurd, because it means that Alfred's murdering Bert is all right in principle. And if it is known that no one else is likely to be threatened in this way by such people in future, and the crime is kept a secret, then it is also all right in practice.

However, what now emerges is that there is a school of thought which supports certain utility-like conclusions without considering itself to be Utilitarian, namely, the "Dirty-Hands" academy. Unlike Utilitarians, who see nothing wrong with riding roughshod over individuals and minorities to their ends - although, of course, they would prefer not to have to do this - these philosophers think that although such things sometimes must be done, they are nevertheless done as "acts of dirty hands - acts that are justified, even obligatory, but none the less wrong and shameful ...” [44].

Raimond Gaita makes the case: "In what follows, one of the ten who might be saved by the shooting of an innocent person calls that shooting evil. I do not think it follows that he must say ... that therefore it must not or ought not be done. Do I intend his speech as an argument that the killing would be evil? Only in this manner and to this degree: it is meant to foreclose one way of talking about the killing and its relation to the ten, to the effect that though, of course, it is terrible it is 'the right thing to do', and so not evil. If he kills one to save ten, even because he believes that 'he must', that 'he must' does not mean that he should not plead for the forgiveness, not only of the one he kills and those related to him, but of those he 'saves' as well.” [45] But, this just seems like expediency with a conscience, and the duty to do the wrong thing a contradiction in terms.

Nevertheless, Dirty-Hands theorists believe that there are some cases - tragic cases - where whatever we do is both right and wrong at the same time. That is, they believe in the possibility of real moral dilemmas. However, this idea appears to derive from taking the descriptor of a moral dilemma - that you are "damned if you do, and damned if you don't” - too literally. For, as Alasdair MacIntyre indicates, [46] a moral dilemma is in fact where more than one option is deemed to be morally necessary - for instance, it is morally incumbent upon Sartre's student both to care for his aged mother and to fight for France - and the agent simply cannot do both [47]. Thus, the student is "damned", but only in the sense that he cannot accomplish both of these equally pressing tasks; not, as the school of dirty-hands maintains, morally. Stocker makes the extraordinary claim that Aristotle 
himself is a member of the dirty-hands group, because Aristotle says "if a tyrant were to order one to do something base, having one's parents and children in his power, and if one did the action they were to be saved, but otherwise would be put to death ...” [48]. He contends that Aristotle holds that the unspecified action is base, yet adjudges that it has to be done anyway, thereby sanctioning dirty-hands [49]. Yet, this is absurd - Aristotle proscribes baseness, as noted above. Moreover, Aristotle also says that "not every action nor passion admits a mean; for some have names that already imply badness, e.g., spite, shamelessness, envy, and in the case of actions adultery, theft, murder ... Therefore: it is not possible, then, ever to be right with regard to them: one must always be wrong." [50] So, if he thinks that under some circumstances doing something wrong is nevertheless a moral duty, his silence about it is deafening. A much more plausible reading of the passage is that the baseness of the means necessary to achieve the end is of a prima facie nature. For instance, let the ransom demanded be cash, and let it be that the amount required can only be obtained by robbery. This seems base, so the agent has a real cause to pause. However, considering that lives are at stake, restitution intended, and that if they have any decency about them the one's "stolen” from will understand, what appears to be base at the outset - viz., to be an act of theft - turns out not to be at all.

The point is that lying, adultery, theft and murder are definitively wrong only to the extent that the words imply unreasonableness. But, not telling the truth to the secret police regarding the whereabouts of their intended victims is not unreasonable, nor is having sex outside of marriage to save someone's life, taking someone else's vehicle in an emergency, or killing someone who is attacking you. Thus, “taking a thing without the owner's knowledge does not always amount to 'theft', but only if it is taken with the intention of keeping it and injuring the owner." [51] Therefore, it is only in so far as the names denote injustices - murder is unjust killing - that these acts are proscribed, since about such things we must always be wrong. Hence, Aristotle also says that "as to adultery, let it be held disgraceful, in general, for any man or woman to be found in any way unfaithful when they are married, and called husband and wife.” [52] This is despite the protestations of certain moral absolutists, who consider themselves to be neo-Aristotelians. For example, Germain Grisez states that "even someone certain he or she was speaking with a person intent on committing murder would not be acting as love requires if, judging that person to be beyond repentance, he or she resorted to lying in an effort to save the potential victim's life.” [53] However, such a position fails to appreciate that circumstances can alter cases to the extent that what is normally wrong can become right. Consequently, whether malevolent individuals are capable of repentance or not is beside the point: they are intent upon committing crimes, and loving and just agents should try to prevent this in whatever ways they can. (Indeed, lying is in fact a charitable response to the potential murderer, if it prevents the person becoming an evil-doer.) For, criminals cannot claim respect for their wishes, when they will not respect the wishes of others. Malevolent and inconsiderate agents - and in their own way this includes gossips - are people who are either intent upon using information to bring harm others, or are nevertheless not unlikely to do so. Therefore, they are unworthy of being told the truth. (Furthermore, if such people are within earshot, not sharing information and even misinforming those who have a genuine right to it, is not unreasonable. For, under the circumstances reasonable people should expect the truth not to be broadcast.)

By parity of reasoning, the rules relating to conjugality, property and life are also not exceptionless. This is because no rights are inviolable - they command respect only in so far as it is reasonable to respect them. Thus, it is ridiculous to think that rights of conjugality and property command respect ahead of life itself, and it is equally absurd to respect in an aggressor the very good which that person threatens to deprive the victim. The point is, if the expectation of one party to a marriage is that fidelity will be preserved at all costs, then this person is either mad or bad, (or some combination thereof), and is consequently unworthy of respect in regard to the expectation. And the same applies to car owners and to killers. Thus, "something of the sort happens also with regard to throwing goods overboard in a storm ... on condition of its securing the safety of himself and his crew any sensible man does so." [54] On the other hand, to have extra-marital sex to make a lover happy, or to rob Peter to pay Paul, or to kill an innocent and non-threatening person to save others lives, cannot be squared with reason, since the values at stake in each case are commensurate, and the goods in question belong to someone else. So, these acts are intrinsically wrong, because they are deliberate violations of others' equal rights.

\section{Laws and Rights}

Therefore, since there are natural rights and doing injustice is the greatest of evils, these rights are first and foremost what the law of the land should be in place to uphold. For, "every state is a community of some kind, and every community is established with a view to some good ...” [55]. But there is no good at all in injustices, so we need the enactment and enforcement of appropriate laws to prevent them. This is because "most people obey necessity rather than argument, and punishments rather 
than the sense of what is noble.” [56] Hence, in Australia, whatever might be intended by it, the Victorian Police Force motto "Uphold the Right" [57] reflects the responsibility of the law to natural justice. Thus, in cases before the courts, whether or not agents took "reasonable care", and acted as any "reasonable person" would do, are matters of determinate significance. Therefore, since "the rightly-framed law does this enacts the natural law rightly, and the hastily conceived one less well" [58], we have processes of judicial review and legal reform. For example, anti-abortion laws in many countries have over the years been relaxed, and continue to be relaxed, in recognition of the rights of women. Naturally, it needs to be considered if these laws are too permissive, because others also have rights. However, women most certainly do have rights over their bodies and their lives, and there is no compelling argument against early abortions for overriding these rights. This is because the case against permitting these abortions goes something like this: "The existence of an immortal soul in the human embryo ... is a philosophical problem from which our moral affirmation that a human life begins at fertilization remains independent for two reasons: 1) supposing a belated animation, there is still nothing less than a human life, preparing for and calling for a soul in which the nature received from parents is completed, 2) on the other hand, it suffices that this presence of the soul be probable (and one can never prove the contrary) in order that the taking of life involve accepting the risk of killing a man, not only waiting for, but already in possession of his soul.” [59] But, the reasoning is wrong-headed. For, if the human conceptus is "first of all alive, then an animal, and finally a man" [60], it is erroneous to refer to "a human life" in the absence of a rational animation, since the definition of "human" is "rational animal". So, the initial conceptus is that-which-will-be-a-man. And, it is wrong to conclude that the presence of mind is "probable" when at best it is esoterically possible. It is not accepted to be there, for instance, when someone is brain-dead. Consequently, in the instance of early abortions, where anti-abortion laws concerning them have been struck down, the rights of women have achieved to this extent the rightful recognition of the law.

\section{Conclusions}

This paper has shown that there is such a thing as another's good in the natural order of things, and therefore that there are natural rights. It has shown that it is a consequence of this that natural justice is fundamental to morality, and trumps any other moral concerns. It has also shown that our laws should be framed principally in terms of these natural rights.

\section{REFERENCES}

[1] St. T. Aquinas, Summa Theologica, 1a2ae. Vol. 18, p. 5, quoting Dionysius.

[2] Aristotle, Nicomachean Ethics, I, p. 7.

[3] Aristotle, Nicomachean Ethics, IV, V, p. 1.

[4] Aristotle, Nicomachean Ethics, V, p. 9.

[5] Aristotle, Rhetoric, I, p. 13.

[6] C. Kluckhohn, "Ethical Relativity, Sic et Non," The Journal of Philosophy, Vol. 52, No. 23, 1955, p. 672.

[7] Aristotle, Nicomachean Ethics, V, p. 1, quoting Plato, Republic, p. 343c.

[8] In: Joannis Evangelium, Vol. 29, as quoted by St T. Aquinas, Summa Theologica, 1a. Vol. 38, 1 ad 1.

[9] In Joannis Evangelium 29; as quoted by St Thomas Aquinas, Summa Theologica, 1a. 38, 1 ad 1.

[10] This is strangely overlooked by John Kilcullen in his "Medieval and Modern Concepts of Rights: How Do They Differ?”, so that he ends up arguing that natural rights should be recognized just because they are "useful". Acta Philosophica Fennica, Vol. 87, 2010, pp. 31-62.

[11] Aristotle, Rhetoric, II, p. 2.

[12] J. Bowring ed., “Anarchical Fallacies,” Works, Vol. 2, 1843.

[13] Sophocles, “The Theban Plays,” Harmondsworth, Penguin, 1967, p. 128.

[14] “After Virtue,” Duckworth, London, 1985, p. 69.

[15] “After Virtue,” Duckworth, London, 1985.

[16] “After Virtue,” Duckworth, London, 1985.

[17] Aristotle, Rhetoric, II, p. 9 (emphasis added).

[18] "The Parable of the Fox and the Unliberated Animals," Ethics, Vol. 88, No. 2, January 1978, p. 122.

[19] P. Singer, "Practical Ethics,” Cambridge University Press, Cambridge, 1995, p. 19.

[20] P. Singer, "Practical Ethics,” Cambridge University Press, Cambridge, 1995.

[21] P. Singer, "Practical Ethics,” Cambridge University Press, Cambridge, 1995, p. 18.

[22] P. Singer, "Practical Ethics,” Cambridge University Press, Cambridge, 1995, p. 17.

[23] P. Singer, "Practical Ethics," Cambridge University Press, Cambridge, 1995, p. 12.

[24] P. Singer, "Practical Ethics," Cambridge University Press, Cambridge, 1995, p. 19.

[25] P. Singer, "Practical Ethics," Cambridge University Press, Cambridge, 1995, p. 22.

[26] G. E. M. Anscombe, "Modern Moral Philosophy”, Ethics Religion and Politics, Oxford, Blackwell, 1981, p. 40.

[27] A. Dongan, “The Theory of Morality,” Chicago, Chicago University Press, 1977, p. 183.

[28] B. Williams, "Morality - An Introduction to Ethics," 
Cambridge University Press, Cambridge, 1990, p. 109.

[29] R. G. Frey, "Rights, Killing and Suffering,” Blackwell, Oxford, 1983, p. 67.

[30] R. G. Frey, "Rights, Killing and Suffering,” Blackwell, Oxford, 1983, p. 81.

[31] R. G. Frey, "Rights, Killing and Suffering,” Blackwell, Oxford, 1983, p. 51.

[32] R. G. Frey, "Rights, Killing and Suffering,” Blackwell, Oxford, 1983, p. 48.

[33] R. Gaita, "Good and Evil:An Absolute Conception," MacMillan, London, 1991, p. 4.

[34] R. Gaita, “Good and Evil:An Absolute Conception," MacMillan, London, 1991.

[35] R. Gaita, “Good and Evil:An Absolute Conception," MacMillan, London, p. 5.

[36] Gorgias, p. 469b.

[37] "Human Personality” as quoted in R. Gaita, "Good and Evil:An Absolute Conception,” MacMillan, London, p. 7.

[38] J. Feinberg, "Freedom and Fulfilment," Princeton University Press, USA, 1992, p. 239.

[39] "Human Personality"; as quoted in R. Gaita "Good and Evil:An Absolute Conception,” MacMillan, London.

[40] Aristotle, Nicomachean Ethics, III, p. 1.

[41] J. J. Thomson, “The Right and the Good”, The Journal of Philosophy, Vol. 94, No. 6, June 1997, p. 276,

[42] Aristotle, Politics, VII, p. 3.

[43] Aristotle, Politics, VII.
[44] M. Stocker, "Plural and Conflicting Values," OUP, Oxford, 1992, p. 9.

[45] R. Gaita, "Good and Evil: An Absolute Conception," MacMillan, London, 1991, p. 69.

[46] R. Gaita, "Good and Evil: An Absolute Conception," MacMillan, London, 1991, p. 224.

[47] J. P. Sarte, “Existentialism is a Humanism,” In: W. Kaufmann, ed., Existentialism from Dostoevsky to Sartre, New American Library, New York, 1975.

[48] Aristotle, Nicomachean Ethics, III, p. 1.

[49] Aristotle, Nicomachean Ethics, III, p. 58.

[50] Aristotle, Nicomachean Ethics, II, p. 6.

[51] Aristotle, Rhetoric, I, p. 13.

[52] Aristotle, Politics, VII, p. 16.

[53] I. L. Quincy, "Living a Christian Life,” Franciscan Press, Illinois, 1993, pp. 406-407.

[54] Aristotle, Nicomachean Ethics, III, p. 1.

[55] Aristotle, Politics, VII, p. 2.

[56] Aristotle, Nicomachean Ethics, X, p. 9. (Surely "most” is exaggerated, "many" more accurate.)

[57] Aristotle, Nicomachean Ethics, X.

[58] Aristotle, Nicomachean Ethics, V, p. 1.

[59] Sacred Congregation for the Doctrine of the Faith, Declaration on Procured Abortion, 18 November, 1974, FN. P. 19.

[60] St T. Aquinas, Summa Theologica, 2a2ae. Vol. 64, p. 1. 